\title{
POTENSI DESA JATIROKE SEBAGAI DESA WISATA
}

\author{
Ute Lies Siti Khadijah ${ }^{1}$, Maharani Citra Praphesti ${ }^{2}$ \\ ${ }^{1}$ Magister Pariwisata Berkelanjutan Sekolah Pascasarjana Universitas Padjadjaran \\ ${ }^{2}$ Program Studi Ilmu Komunikasi Fakultas Ilmu Komunikasi Universitas Padjadjaran \\ E-mail ute.lies@unpad.ac.id
}

\begin{abstract}
Abstrak. Desa Jatiroke selama perkembangannya hingga saat ini mempunyai beberapa masalah. Yang pertama adalah belum dikelolanya berbagai potensi desa yang sebenarnya dapat dikembangkan dengan baik, mulai dari Gunung Geulis hingga berbagai kesenian daerah yang masih kuat dan terjaga dengan cukup baik. Selanjutnya adalah rendahnya tingkat pengetahuan dan keterampilan para warga desa, mulai dari penggunaan teknologi hingga pemanfaatan potensi-potensi desa, dan lain-lain. Yang ketiga berkaitan dengan badan pengurus desa yang merupakan kurang efektifnya komunikasi dan kerja sama antara pemerintah desa dan warga desa serta desa yang masih mengandalkan bantuan dari pemerintah dan kurangnya bantuan dari berbagai pihak swasta yang akhirnya mempengaruhi kondisi keuangan desa. Desa Jatiroke selama perkembangannya hingga saat ini. Yang pertama adalah belum dikelolanya berbagai potensi desa yang sebenarnya dapat dikembangkan dengan baik, mulai dari Gunung Geulis hingga berbagai kesenian daerah yang masih kuat dan terjaga dengan cukup baik. Selanjutnya adalah rendahnya tingkat pengetahuan dan keterampilan para warga desa, mulai dari penggunaan teknologi hingga pemanfaatan potensi-potensi desa, dan lain-lain. Yang ketiga berkaitan dengan badan pengurus desa yang merupakan kurang efektifnya komunikasi dan kerja sama antara pemerintah desa dan warga desa serta desa yang masih mengandalkan bantuan dari pemerintah dan kurangnya bantuan dari berbagai pihak swasta yang akhirnya mempengaruhi kondisi keuangan desa. Penelitian ini menggunakan metode RRA atau Rapid Rural Appraisal. Metode ini merupakan proses belajar intensif untuk memahami kondisi masyarakat, yang dilakukan secara berulang dan cepat. Kelebihan pendekatan ini adalah penelitian bisa mencakup daerah yang lebih luas dalam waktu relatif singkat untuk mendapatkan informasi yang luas secara umum. Dalam metode ini, informasi yang dikumpulkan terbatas pada data yang dibutuhkan sesuai dengan tujuan penelitian, namun dilakukan dengan lebih mendalam dengan menelusuri sumbernya sehingga didapatkan informasi yang lengkap tentang sesuatu hal. Hasil Penelitian adalah diketahui ada dua masalah utama yang dimiliki oleh desa Jatiroke. Yang pertama adalah berbagai potensi yang terdapat di desa yang belum diberdayakan dengan baik oleh masyarakat sekitar sendiri hingga pengurus desa. Potensi tersebut sangat beragam macamnya, mulai dari potensi alam, potensi budaya, hingga potensi sumber daya masyarakatnya. Masalah kedua yang terjadi adalah bagaimana desa secara keseluruhan belum bisa dijadikan sebagai sebuah aset karena kurangnya pengelolaan sarana dan prasarana desa. Dari berbagai permasalahan tersebut, salah satu solusi yang bisa dilakukan adalah pemanfaatan desa Jatiroke sebagai sebuah desa wisata. Dalam mengembangkan sebuah desa wisata, terdapat berbagai cara yang bisa dilakukan seperti memperbaiki berbagai infrastruktur desa, mengembangkan potensi budaya, serta melakukan pengembangan teknologi dengan menggunakan media sosial dan website sebagai salah satu bentuk komunikasi pemasaran. Seluruh cara ini dapat dilakukan untuk mengembangkan desa Jatiroke sebagai sebuah desa wisata sehingga bisa dikenal oleh masyarakat luas yang akhirnya dapat meningkatkan tingkat perekonomian warga desa Jatiroke itu sendiri
\end{abstract}

Kata kunci; desa wisata, marketing, gunung Geulis

\section{POTENTIAL OF JATIROKE VILLAGE AS A TOURIST VILLAGE}

Astract. Jatiroke Village during its development until now has several problems. The first is the lack of management of various village potentials that can actually be well developed, starting from Gunung Geulis to various local arts which are still strong and well-maintained. Next is the low level of knowledge and skills of villagers, ranging from the use of technology to the utilization of village potentials, and others. The third relates to the village management body which is the lack of effective communication and cooperation between the village government and villagers and villages that still rely on government assistance and the lack of assistance from various private parties which ultimately affects the village's financial condition. Jatiroke village during its development until now. The first is not yet managed various potential villages that can actually be developed properly, starting from Gunung Geulis to various regional arts that are still strong and well-maintained. Next is the low level of knowledge and skills of villagers, ranging from the use of technology to the utilization of village potentials, and others. The third relates to the village management body which is the lack of effective communication and cooperation between the village government and villagers and villages that still rely on government assistance and the lack of assistance from various private parties which ultimately affects the village's financial condition. This research uses the RRA or Rapid Rural Appraisal method. This method is an intensive learning process to understand the condition of the community, which is carried out repeatedly and quickly. The advantage of this approach is that research can cover a wider area in a relatively short time to obtain broad information in general. In this method, the information collected is limited to the data needed in accordance with the purpose of the study, but is carried out in more depth by tracing the source so that complete information about something is obtained. The results of the study are known to have two main problems that are owned by Jatiroke village. The first is the various potentials in the village that have not been properly empowered by the surrounding community to the village administrators. The potential is very diverse, ranging from natural potential, cultural potential, to the potential of community resources. The second problem that occurs is how the village as a whole cannot be used as an asset due to the lack of management of village facilities and infrastructure. Of the various problems, one solution that can be done is the use of Jatiroke village as a tourist village. In developing a tourist village, there are various ways that can be done such as improving various village infrastructure, developing cultural potential, and developing technology using social media and websites as a form of marketing communication. All of these methods can be done to develop the Jatiroke village as a tourist village so that it can be recognized by the wider community which ultimately can increase the economic level of the Jatiroke villagers themselves. 


\section{PENDAHULUAN}

Desa Jatiroke selama perkembangannya hingga saat ini. Yang pertama adalah belum dikelolanya berbagai potensi desa yang sebenarnya dapat dikembangkan dengan baik, mulai dari Gunung Geulis hingga berbagai kesenian daerah yang masih kuat dan terjaga dengan cukup baik. Selanjutnya adalah rendahnya tingkat pengetahuan dan keterampilan para warga desa, mulai dari penggunaan teknologi hingga pemanfaatan potensi-potensi desa, dan lain-lain. Yang ketiga berkaitan dengan badan pengurus desa yang merupakan kurang efektifnya komunikasi dan kerja sama antara pemerintah desa dan warga desa serta desa yang masih mengandalkan bantuan dari pemerintah dan kurangnya bantuan dari berbagai pihak swasta yang akhirnya mempengaruhi kondisi keuangan desa. Yang terakhir adalah sarana dan prasarana desa yang masih belum terfasilitasi dengan baik, hal ini tentu saja akan berpengaruh pada daya tarik para wisatawan untuk datang dan mengunjungi desa Jatiroke. Dalam sektor sumber daya manuisa, dari 6.586 jumlah penduduk yang berada dalam usia produktif, berdasarkan data Desa Jatiroke terdapat 1.754 orang yang tidak/belum bekerja dan 1.232 orang ibu rumah tangga yang merupakan sumber daya manusia yang belum diberdayakan dengan maksimal. Dari jumlah yang tidak sedikit ini sebenarnya potensi yang didapatkan bisa sangat melimpah apabila para tenaga kerja ini diberikan pelatihan serta penyuluhan. Selain itu para calon tenaga kerja yang masih bersekolah juga bisa mulai diberikan pelatihan agar meningkatkan kualitas mereka sehingga dapat turut berperan dalam pembangunan desa. Desa wisata adalah desa yang terdapat potensi dan daya tarik wisata baik secara fisik lingkungan alamnya maupun kehidupan soSial budayanya serta dikelola dengan baik agar dapat menggerakkan ekonomi dan pemberdayaan masyarakat setempat (Muliawan, 2008). Menurut Muliawan (Muliawan, 2008) prinsip pengembangan desa wisata adalah sebagai salah satu produk wisata alternatif yang dapat memberi dorongan bagi pembangunan pedesaan yang berkelanjutan. Desa wisata juga memiliki prinsip pengelolaan yaitu untuk memanfaatkan sarana dan prasarana setempat, menguntungkan masyarakat setempat, berskala kecil untuk memudahkan terjalinnya hubungan timbal balik dengan masyarakat setempat, serta melibatkan masyarakat dan menerapkan pengembangan produk wisata pedesaan. Kriteria desa wisata menurut Muliawan adalah desa yang memiliki potensi keunikan dan daya tarik wisata, memiliki dukungan dan kesiapan fasilitas pendukung seperti adanya penginapan/akomodasi, terdapat ruang interaksi antara wisatawan dengan masyarakat, serta dukungan inisiatif dan partisipasi masyarakat setempat terhadap pengembangan desa (Muliawan, 2008). Setiap desa pasti memiliki potensinya masing-masing yang nantinya dapat dikembangkan oleh para warganya. Ada yang memiliki potensi alam yang melimpah, potensi dalam bidang budaya, potensi dalam bidang wisata, dan lain-lain. Seluruh potensi tersebut tentu saja harus dikelola dengan caranya masing-masing. Sebuah desa yang memiliki potensi alam yang sangat melimpah, tentu saja tidak bisa dikembangkan hanya dalam sektor budayanya saja. Salah satu desa yang memiliki potensi besar namun belum dikembangan dengan baik adalah desa Jatiroke di Jatinangor, Sumedang. Desa ini terletak di Keca- matan Jatinangor dan memiliki luas wilayah 257.083 Ha. Seperti desa-desa pada umumnya, desa Jatiroke memiliki lembaga kemasyarakatan dan kelompok warga yang membantu perkembangan dan pembangunan desa. Penulis telah melakukan wawancara dan survei kepada beberapa warga desa Jatiroke, mulai dari warga biasa, perwakilan Karang Taruna, serta Badan Pengurus Desa. Dari hasil penelitian tersebut, penulis menemukan berbagai potensi yang sebenarnya bisa dikelola dan dikembangkan oleh para warga desa Jatiroke.

Berbagai potensi tersebut sangat beragam, mulai dari potensi dalam sektor budaya hingga potensi alam. Desa Jatiroke masih memiliki berbagai seni dan budaya leluhur yang cukup terpelihara dengan baik oleh para warganya, mulai dari Pencak Silat, Kuda Renggong, Marawis, Reak, hingga Singa Depok. Kesenian ini cukup terpelihara dengan baik karena para warga Desa Jatiroke, mulai dari yang sudah tua hingga yang masih muda, sudah dikenalkan dan cukup akrab dengan berbagai kesenian ini.

Potensi selanjutnya yang bisa dikembangkan oleh para warga Desa Jatiroke adalah potensi alam yaitu Gunung Geulis. Dengan adanya Gunung Geulis ini sebenarnya bisa dijadikan sebagai salah satu daya tarik wisata untuk desa Jatiroke. Namun berbeda dengan keseniannya, Gunung Geulis ini belum dikelola dengan baik oleh para warganya. Padahal sebenarnya Gunung Geulis ini merupakan salah satu aset berharga yang sangat bisa dimanfaatkan oleh para warganya untuk meningkatkan taraf ekonomi serta kesejahteraan warga desa. Masih berkaitan dengan potensi alam, berdasarkan data yang penulis dapatkan, masih terdapat tanah kering seluas 75.508 Ha dari total wilayah seluas 257.083 Ha yang belum dimanfaatkan secara maksimal oleh para warga desa Jatiroke. Dari berbagai masalah tersebut, dapat ditemukan bahwa masalah utama yang dimiliki oleh desa Jatiroke adalah banyaknya potensi desa yang belum dimanfaatkan dengan baik. Padahal apabila potensi-potensi ini dapat dimanfaatkan secara maksima, tentu saja dapat menguntungkan berbagai macam pihak, mulai dari pendapatan desa hingga pendapatan pribadi para warga. Realitas yang terjadi tersebutlah yang menjadi alasan dibuatnya penelitian ini. Dapat dirumuskan bahwa rumusan masalah penelitian ini adalah bagaimana solusi dalam memberdayakan masyarakat serta memperkenalkan potensi Desa Jatiroke sebagai desa wisata? Tujuan dari penelitian ini adalah untuk mengetahui potensi Desa Jatiroke, mengembangkan potensi Desa Jatiroke sebagai desa wisata melalui pemberdayaan masyarakat, serta meningkatkan taraf ekonomi Desa Jatiroke.

\section{METODE}

Penelitian ini menggunakan metode RRA atau Rapid Rural Appraisal. Metode ini merupakan proses belajar intensif untuk memahami kondisi masyarakat, yang dilakukan secara berulang dan cepat. Kelebihan pendekatan ini adalah penelitian bisa mencakup daerah yang lebih 
luas dalam waktu relatif singkat untuk mendapatkan informasi yang luas secara umum. Dalam metode ini, informasi yang dikumpulkan terbatas pada data yang dibutuhkan sesuai dengan tujuan penelitian, namun dilakukan dengan lebih mendalam dengan menelusuri sumbernya sehingga didapatkan informasi yang lengkap tentang sesuatu hal. Jadi dapat disimpulkan bahwa metode RRA dipusatkan pada pemahaman tingkat komunitas lokal yang digabungkan dengan pengetahuan ilmiah. Terdapat tiga konsep dasar metode RRA, yaitu perspektif sistem, triangulasi dari pengumpulan data, pengumpulan data dan analisis secara berulang. Empower atau berdaya dalam kamus bahasa ditafsirkan sebagai "berkontribusi waktu, tenaga, usaha melalui kegiatan berkenaan dengan perlindungan hukum", "memberikan seseorang atau sesuatu kekuatan atau persetujuan melakukan sesuatu", "menyediakan seseorang dengan sumber daya, otoritas, dan peluang untuk melakukan sesuatu", atau "membuat sesuatu menjadi mungkin dan layak". Pada kamus yang lain, pengertian berdaya menjadi "memberikan seseorang rasa percaya diri atau kebangaan diri”.

\section{HASIL DAN PEMBAHASAN}

Desa Jatiroke yang memiliki beragam potensi yang seharusnya bisa dimanfaatkan dengan baik agar dapat memajukan pembangunan desa menuju yang lebih baik ke depannya, mulai dari sumber daya manusia, sumber daya alam, hingga potensi sosial budayanya.

Berdasarkan data badan pengurus desa Jatiroke, per tahun 2017, desa Jatiroke dihuni oleh 6.741 jiwa, dengan 3.455 penduduk laki-laki serta 3.286 penduduk perempuan. Sesuai data yang diberikan oleh badan pengurus desa Jatiroke, klasifikasi jumlah penduduk berdasarkan umur pada tahun 2015 adalah sebagai berikut.

Tabel 1. Penduduk Desa Jatiroke Menurut Umur Tahun 2015

\begin{tabular}{|c|c|}
\hline \multirow{2}{*}{ UMUR } & $\begin{array}{c}\text { PENDUDUK MENURUT } \\
\text { UMUR }\end{array}$ \\
\cline { 2 - 2 } 00-04 Tahun & 264 \\
\hline 05-06 Tahun & 237 \\
\hline 7-12 Tahun & 884 \\
\hline 13-15 Tahun & 401 \\
\hline 16-18 Tahun & 398 \\
\hline 19-25 Tahun & 873 \\
\hline 26-64 Tahun & 3.294 \\
\hline 65 Tahun keatas & 390 \\
\hline Jumlah & $\mathbf{6 . 7 4 1}$ \\
\hline
\end{tabular}

Sumber : Data Desa Jatiroke, 2017

Dari data tersebut dapat dilihat bahwa hampir 50\% penduduk desa Jatiroke merupakan masyarakat yang berusia produktif namun penduduk yang sudah memiliki kemampuan yang memadai masih sedikit. Hanya $3 \%$ dari masyarakat desa Jatiroke yang dapat menyelesaikan pendidikan perguruan tinggi dan hanya 20\% yang menyelesaikan pendidikan Sekolah Menengah Atas. Dari tingkat pendidikan yang rendah tersebut menyebabkan masyarakat Jatiroke belum memiliki pekerjaan yang layak dan hanya memanfaatkan hasil kekayaan alam secara seadanya yang berada di desa Jatiroke. Berikut merupakan data mengenai mata pencaharian masyarakat Jatiroke:

Tabel 2. Mata Pencaharian Penduduk Desa Jatiroke Tahun 2015

\begin{tabular}{|l|r|}
\hline \multicolumn{1}{|c|}{ PROFESI } & JUMLAH (JIWA) \\
\hline Tidak / Belum bekerja & 1.754 \\
\hline Ibu Rumah Tangga & 1.232 \\
\hline Pelajar/Mahasiswa & 1.122 \\
\hline Pensiunan & 41 \\
\hline PNS & 65 \\
\hline TNI/POLRI & 22 \\
\hline Petani & 213 \\
\hline Buruh & 214 \\
\hline Pegawai Swasta & 905 \\
\hline Wiraswasta & 906 \\
\hline Lain-lain & 112 \\
\hline JUMLAH & $\mathbf{6 . 5 8 6}$ \\
\hline
\end{tabular}

Sumber : Data Desa Jatiroke, 2017

Berdasarkan tabel di atas, masih terdapat lebih dari $45 \%$ masyarakat Jatiroke yang belum memiliki pendapatan yang jelas. Untuk masyarakat yang sudah bekerja, mereka belum memiliki pekerjaan yang layak. Pekerjaan yang dimiliki oleh para masyarakat Jatiroke adalah sebagai buruh tani atau buruh pabrik. Selain itu beberapa warga Jatiroke juga memiliki berbagai usaha-usaha kerajinan, warung, gilingan padi, kelontong, toko, home industry, dan peternakan yang belum dikelola dan dikembangkan secara maksimal. Apabila dilihat dari segi keuangan desa, Jatiroke masih mengandalkan bantuan dari pemerintah sementara untuk pendapatan asli desa dan bantuan pihak ketiga atau pihak swasta masih sangat kurang.

Jatiroke memiliki salah satu kelebihan yang merekat diantara para warganya, yaitu rasa kekeluargaan yang melekat kuat satu sama lain. Hal tersebut dapat dilihat dari banyaknya kelompok masyarakat yang membantu pemerintah dalam pelaksanaan pembangunan dan pemberdayaan masyarakat, seperti Badan Permusyawaratan Desa (BPD), Lembaga Pemberdayaan Masyarakat Desa (LPMD), Pemberdayaan Kesejahteraan Keluarga (PKK), Perlindungan Masyarakat (LINMAS), Karang Taruna, Majelis Ulama, Dewan Kesejahteraan Mesjid (DKM), Kelompok Tani. Selanjutnya apabila dilihat dari potensi sumber daya alamnya, Jatiroke memiliki sebuah aset yang sangat berpotensi untuk dikembangkan yaitu Gunung Geulis. Selain itu, Jatiroke juga memiliki berbagai kesenian dan budaya leluhur yang terpelihara dengan baik seperti Reak, Pencak Silat, Kuda Renggong, Singa Depok, dan lainnya. Dapat disimpulkan bahwa sebenarnya Desa Jatiroke patut dipertimbangkan sebagai desa yang seharusnya dapat berkembang dengan baik. 
Fakta yang ada di lapangan menyatakan bahwa beragam potensi yang ada di desa Jatiroke ini belum bisa dimaksimalkan dengan baik. Berdasarkan wawancara yang dilakukan kepada Bapak Yadi sebagai Kepala Urusan dan anggota Karang Taruna Desa Jatiroke, sebenarnya target awal dalam membangun Desa Jatiroke adalah menjadikannya sebagai objek wisata karena dirasa dapat meningkatkan pendapatan asli daerah, namun sayangnya hal tersebut belum terealisasi hingga saat ini. Aksesibilitas Gunung Geulis juga masih belum terstruktur dengan baik dan belum memiliki sistem pendakian yang jelas. Gunung Geulis sendiri belum memiliki pos pendakian, pendataan calon pendaki Gunung, dan tidak memiliki sarana prasarana apapun untuk menunjang Gunung Geulis sebagai tempat wisata. Menurut Bapak Yadi, terdapat banyak program yang disusun untuk mengembangkan Gunung Geulis namun hanya sekedar wacana saja.

Dari data yang didapatkan, sebagian besar pendaki Gunung Geulis merupakan mahasiswa Universitas Padjadjaran. Berdasarkan sudut pandang pendaki Gunung Geulis yang mayoritas adalah mahasiswa Unpad menyatakan bahwa sebenarnya Gunung Geulis memiliki daya tarik yang dapat memikat para pendaki. Menurut mereka, dari atas Gunung Geulis dapat terlihat keindahan Jatinangor, cahaya kota di malam hari. Keunikan Gunung Geulis yang juga cukup menarik perhatian para pendakinya adalah adanya makam leluhur yang terletak di puncaknya. Letak Gunung Geulis yang juga berdekatan dengan lokasi kampus dan pendakian yang tidak memakan waktu lama merupakan pertimbangan lain mahasiswa Unpad dalam mendaki gunung ini. Salah satu hal yang disayangkan oleh para pendakinya adalah Gunung Geulis belum memiliki posko pendakian, jalur pendakian yang belum teratur, dan sampah yang berserakan dimana-mana.

Berdasarkan serangkaian potensi yang kurang dimanfaatkan di Desa Jatiroke, maka perlu diterapkan konsep pemberdayaan masyarakat secara bottom up dan partisipatoris. Program yang dibuat harus sesuai dengan kebutuhan dan potensi yang dimiliki oleh masyarakat melalui pemberdayaan masyarakat. Penulis akan memposisikan masyarakat Jatiroke bukan sebagai "korban pembangunan" namun lebih berperan sebagai "pelaku pembangunan". Seseorang akan diberikan tanggung jawab dan kebebasan atas program dan ide yang telah disusun bersama sehingga mereka bisa lebih berkembang dan menghilangkan paradigma bahwa "orang miskin akan selamanya miskin". Konsep pemberdayaan disini memiliki tujuan dua arah, yaitu untuk melepaskan belenggu kemiskinan dan keterbelakangan, kedua untuk memperkuat posisi lapisan masyarakat dalam struktur ekonomi dan masyarakat. Hal tersebut sejalan dengan tujuan yang telah dituliskan penulis yang ingin mengembangkan potensi desa melalui pemberdayaan dan meningkatkan taraf ekonomi desa melalui aset yang telah dimiliki oleh Desa Jatiroke.

Dari konsep pemberdayaan tersebut konsep Integrated Marketing Communication dapat diaplikasikan sebagai sarana untuk memperkenalkan potensi wisata yang ada di desa Jatiroke. Dengan adanya komunikasi pemasa- ran yang telah berjalan dengan baik tentu saja dapat dijadikan sebagai sarana untuk memperkenalkan desa Jatiroke sebagai desa wisata. Komunikasi pemasaran yang dilakukan dapat dimulai dari pembangunan desa Jatiroke sebagai desa wisata, pemberdayaan masyarakat untuk memanfaatkan setiap aset yang ada serta memperkenalkan setiap aset tersebut kepada para calon wisatawan yang berkunjung. Media pengenalan asset tersebut dapat dilakukan melalui teknologi media sosial yang semakin berkembang seiring berjalannya waktu. Warga desa Jatiroke dapat diberikan pelatihan berbasis teknologi agar mereka paham dan mengerti mengenai perkembangan teknologi serta bagaimana cara mengelola teknologi tersebut dengan baik.

Penulis menggunakan metode RRA untuk memperoleh informasi lokal yang nantinya dapat digunakan untuk tujuan penelitian dan solusi bagi rencana pembangunan melalui observasi dan wawancara. Dari pelaksanaan observasi dapat diketahui pemetaan permasalahan dan potensi yang dimiliki desa Jatiroke serta penyesuaian dengan konsep yang diusung. Dari hasil observasi penulis melihat perlu adanya kerjasama dari semua pihak untuk dapat memaksimal potensi serta memberdayakan masyarakat. Pemberdayaan masyarakat penting untuk dilakukan agar sumber daya manusia yang dimiliki oleh desa Jatiroke dapat dengan bebas dan mandiri memanfaatkan potensi lainya, baik alam maupun potensi sosial budaya yang dimiliki. Alur komunikasi juga perlu dikembangkan dengan baik dan jelas baik dari pemerintah desa kepada masyarakat, begitu pula sebaliknya.

Dari pelaksanaan wawancara kepada badan pengurus desa serta masyarakat desa Jatiroke, masalah utama yang dihadapi adalah kurangnya komunikasi antara para warga dan pengurus desa. Hal ini dapat diketahui dari warga yang tidak mengetahui berbagai program yang dimiliki pengurus desa untuk memberdayakan warganya. Solusi yang bisa ditawarkan dari permasalahan ini adalah melakukan forum komunikasi secara berkala untuk melaksanakan sosialisasi berbagai rencana dari aparat desa dengan masyarakat. Hal ini dapat meminimalisir masalah komunikasi serta melibatkan partisipasi aktif warga untuk lebih mengenal potensi desanya.

Apabila sudah terjadi kesepahaman antara pengurus desa dan masyarakat, langkah selanjutnya yang ditawarkan sebagai solusi adalah melaksanakan program komunikasi pemasaran untuk meningkatkan tingkat awareness para calon wisatawan yang masih asing dengan wisata desa Jatiroke. Dari potensi desa dan jumlah penduduk usia produktif yang ada sebenarnya sangat memungkinkan untuk mengembangkan desa Jatiroke sebagai desa wisata yang memiliki fokus kepada wisata alam dan budaya. Dalam proses pengembangan desa wisata ini tentu perlu dilakukan perbaikan sarana dan prasarana yang dapat menunjang daya tarik desa Jatiroke sebagai desa wisata, mulai dari akses jalan, petunjuk arah, tempat peristirahatan, tempat sholat, jalur pendakian yang memadai, serta posko pendakian. 
Warga sekitar desa Jatiroke juga dapat dimanfaatkan sebagai penginapan para pendaki gunung sebagai sebuah homestay. Dengan pemanfaatan rumah warga sebagai homestay tersebut tentunya dapat meningkatkan taraf ekonomi para warga desa Jatiroke sebagai salah satu sumber penghasilan. Selain itu, warga desa Jatiroke juga dapat mengembangkan dan memperkenalkan berbagai budaya yang terdapat di desa Jatiroke sebagai salah satu sarana untuk menguatkan konsep desa wisata. Bentuk pengenalan budaya sekitar ini dapat dilakukan dengan pembuatan souvenir atau pembuatan trip wisata dengan memanfaatkan warga sekitar sebagai guide. Trip wisata ini dapat dibuat dengan memanfaatkan berbagai potensi yang ada di desa Jatiroke, mulai dari makanan daerah sekitar, kegiatan kebudayaan, serta berbagai kegiatan lainnya yang dapat menarik minat para calon wisatawan. Berbagai potensi budaya ini bisa dimanfaatkan salah satunya dengan pengadaan kegiatan festival kesenian sebagai salah satu ciri khas dari desa Jatiroke. Dengan kegiatan festival ini juga tentu dapat menguatkan branding image dari desa Jatiroke sebagai sebuah desa wisata dan dapat menarik perhatian calon wisatawan.

Penguatan branding image ini juga bisa dilakukan dengan cara memanfaatkan teknologi dan media sosial. Saat ini teknologi dan media sosial memang sudah menjadi salah satu sumber media utama bagi masyarakat. Dengan teknologi yang semakin berkembang ini tentu saja dapat dimanfaatkan sebagai salah satu ajang untuk mempromosikan desa Jatiroke. Namun masalah yang akan dihadapi selanjutnya adalah kurangnya pengetahuan para warga mengenai literasi terhadap teknologi. Sehingga salah satu saran yang bisa dilakukan adalah melaksanakan workshop untuk melatih dan mengajarkan pengetahuan mengenai penggunaan teknolgi yang baik dan benar. Dari hasil workshop ini nantinya akan mendapatkan hasil pemasaran desa yang lebih baik dari sebelumnya. Warga Jatiroke dapat membuat website dan media sosial untuk melakukan publikasi agar masyarakat luar dapat mengetahui tentang potensi yang dimiliki oleh desa.

Ketika seluruh solusi tersebut dapat berjalan dengan baik, maka desa wisata Jatiroke akan benar-benar terwujud dan bisa dimanfaatkan hasilnya. Salah satu catatan yang perlu diperhatikan adalah semua rancangan ini harus terintegrasi dengan baik antara satu hal dengan yang lainnya. Dengan pembangunan sarana dan prasarana yang baik, tentu saja desa Jatiroke dapat dipasarkan secara menarik. Dengan seluruh warga yang saling bahu membahu untuk mengembangkan industri wisata dalam bentuk homestay atau travel guide juga tentu dapat membantu berjalannya program ini agar bisa semakin baik ke depannya. Di dalam website dan media sosial yang dibuat oleh warga juga dapat dicantumkan berbagai paket wisata sehingga masyarakat luar bisa dengan mudah menikmati berbagai wisata yang ditawarkan oleh desa Jatiroke sehingga lebih banyak calon wisatawan yang akan tertarik berkunjung dan berwisata.

\section{SIMPULAN}

Dari penelitian yang telah dilakukan sebelumnya, mulai dari pengumpulan data melalui tahap observasi, wawancara dan proses analisis data dapat diketahui berbagai masalah dan potensi yang dimiliki oleh desa Jatiroke. Diketahui ada dua masalah utama yang dimiliki oleh desa Jatiroke. Yang pertama adalah berbagai potensi yang terdapat di desa yang belum diberdayakan dengan baik oleh masyarakat sekitar sendiri hingga pengurus desa. Potensi tersebut sangat beragam macamnya, mulai dari potensi alam, potensi budaya, hingga potensi sumber daya masyarakatnya. Masalah kedua yang terjadi adalah bagaimana desa secara keseluruhan belum bisa dijadikan sebagai sebuah aset karena kurangnya pengelolaan sarana dan prasarana desa.

Dari berbagai permasalahan tersebut, salah satu solusi yang bisa dilakukan adalah pemanfaatan desa Jatiroke sebagai sebuah desa wisata. Dalam mengembangkan sebuah desa wisata, terdapat berbagai cara yang bisa dilakukan seperti memperbaiki berbagai infrastruktur desa, mengembangkan potensi budaya, serta melakukan pengembangan teknologi dengan menggunakan media sosial dan website sebagai salah satu bentuk komunikasi pemasaran. Seluruh cara ini dapat dilakukan untuk mengembangkan desa Jatiroke sebagai sebuah desa wisata sehingga bisa dikenal oleh masyarakat luas yang akhirnya dapat meningkatkan tingkat perekonomian warga desa Jatiroke itu sendiri

\section{DAFTAR PUSTAKA}

Amanah, S. "Peran Komunikasi Pembangunan dalam Pemberdayaan Masyarakat Pesisir." Jurnal Komunikasi Pembangunan, Vol 8, no 1, 2010: 1 - 19.

Atmoko, Prasetyo Hadi. "Strategi Pengembangan Potensi Desa Wisata Brajan Kabupaten Sleman." Jurnal Media Wisata, Volume 12, Nomor 2, 2014: 146 - 154.

Imanuddin, Abdul Malik. "Desa Jatiroke." Sumedang Tandang. 08 Februari 2017. http://sumedangtandang. com/direktori/detail/desa-jatiroke.htm (diakses April 13, 2018).

—. "Gunung Geulis." Sumedang Tandang. 4 Maret 2016. http://sumedangtandang.com/direktori/detail/ gunung-geulis.htm (diakses April 13, 2018).

Indardi. Komunikasi Pemberdayaan Masyarakat. Bandung: Unpad Press, 2009.

Muliawan, H. Pengembangan Pariwisata Berbasis Masyarakat Konsep dan Implementasi. 2008.

Noor, Munawar. "Pemberdayaan Masyarakat.” Jurnal Ilmiah Civis, Volume 1, No 2, 2011: 87 - 99.

Sulaksana, Uyung. Integrated Marketing Communication. Yogyakarta: Pustaka Pelajar, 2003. 